\title{
自己決定理論による在日外国人留学生のアルバイト満足感と疲労感の検討
}

閻 琳（立命館大学 総合心理学部, yan-1@fc.ritsumei.ac.jp）

堀内 孝（岡山大学大学院社会文化科学研究科, horiuchi@okayama-u.ac.jp)

\section{Examination of part-time job satisfaction and exhaustion of international students in Japan based on self-determination theory}

Lin Yan (College of Comprehensive Psychology, Ritsumeikan University, Japan)

Takashi Horiuchi (Graduate School of Humanities and Social Sciences, Okayama University, Japan)

\begin{abstract}
The present study examined how job satisfaction and exhaustion are affected by motivational regulation and style in the part-time jobs of international students in Japan, based on self-determination theory. A multivariate regression analysis, which included five motivational regulations as independent variables and job satisfaction and exhaustion as dependent variables, was conducted. The results showed that job satisfaction was positively correlated with intrinsic regulation and identified regulation and negatively correlated with introjected regulation. For exhaustion, a negative correlation was shown with intrinsic regulation, and a positive correlation was shown with extrinsic and identified regulation. The results of a cluster analysis based on five motivational regulations revealed four motivational styles. High motivational styles were shown to have the highest job satisfaction, and low intrinsic/high extrinsic styles were shown to have the highest exhaustion.
\end{abstract}

\section{Key words}

international students in Japan, part-time employment, motivational regulation and style, job satisfaction, exhaustion

\section{1.はじめに}

平成 20 年に、「グローバル戦略」展開の一環として「留 学生 30 万人計画 (文部科学省・外務省・法務省・厚生労 働省・経済産業省・国土交通省，2008）」が発表されて以降、 日本に留学する外国人学生が増え、留学生に対する関心 が高まってきた。独立行政法人日本学生支援機構（2019b） によると、平成 20 年時点で在日外国人留学生の数（日本 語教育機関を対象外）は 123,829 人であったが、平成 27 年には初めて 20 万人 $(208,379$ 人) を突破し、平成 30 年 は 298,980 人となり、外国人留学生の数が急増している趨 勢が明らかとなった。そして、日本に留学した外国人学 生のうち 298,461 人が労働者として雇用されていることか ら（厚生労働省，2019）、留学生のほぼ全員（全体の99.83 \%)がアルバイト活動に従事していると推定される。また、 独立行政法人日本学生支援機構（2019a）によると、1 週 間のアルバイトの時間数について、「週 20 時間以上 25 時 間未満」が最も多く (35.5\%)、週 15 時間以上と回答した 者が全体の $69.8 \%$ を占めていると記されている。多くの 在日外国人留学生はアルバイト活動を体験しており、ア ルバイト活動は留学生活において頻繁に行われる活動の 1 つになっている。

そのような労働実態を勘案して、閻・堀内（2017; 2019）は、自己決定理論（Self-determination theory: Deci \& Ryan, 1985; Ryan \& Deci, 2000）という動機づけ現象全般に 関わる理論に立脚し、在日外国人留学生のアルバイト活 動に関する一連の研究を行っている。自己決定理論とは、
内発的動機づけと外発的動機づけを自己決定性の程度と いう連続帯上で統合して捉える理論である（Deci \& Ryan, 1985; Ryan \& Deci, 2000)。すなわち、自己決定理論では、 内発的動機づけを内発的調整という最も自己決定性の高 い段階に位置づけ、外発的動機づけを自己決定的な順に、 統合的調整、同一化的調整、取り入れ的調整、外的調整 と分類している。また、自己決定理論は精神的健康や適 応的な心理状態を予測する理論であり、より自己決定的 に動機づけられた行動は適応的な結果をもたらすことが 明らかにされている（永作・新井, 2005 ; 岡田, 2005)。閻・ 堀内（2017）は在日外国人留学生のアルバイト活動を対 象に、内発的調整、統合的調整、同一化的調整、取り入 れ的調整、外的調整という5 因子からなるアルバイト動 機づけ尺度を作成した。そして、閻・堀内（2019）はア ルバイト活動における基本的な心理欲求（自律性・有能感・ 関係性）の充足によって、自律的な動機づけ（内発的調整・ 統合的調整・同一化的調整）が高くなり、さらに、その 自律的な動機づけが高い職務満足感をもたらすことを明 らかにしている。

ところで、異文化適応の途上にある留学生にとってア ルバイト活動を行うことは、日本語能力や対人関係スキ ルなどの不足から、日本人学生以上に困難でエネルギー を要することは想像に難くなく、職場における不適応も 生じやすいと考えられる。本研究では、アルバイト活動 における不適応を検討するため、職場ストレス反応の中 核的反応である疲労感（島津・小杉，1998）を不適応指標 として取り上げる。仕事領域では、自己決定的な動機づ けは高い職務満足感をもたらすとともに、疲労感を低減 することが知られている (Richer, Blanchard, \& Vallerand, 2002; Roth, Assor, Kanat-Maymon, \& Kaplan, 2007)。たとえ 
ば、Richer et al.（2002）は動機づけの自己決定性の程度 が職務満足感に対して正の影響、感情的な疲労感に対し て負の影響を及ぼすことを見出している。また、教師の 自律的な動機づけに関して検討した Roth et al. (2007) で は、疲労感は、動機づけの自己決定性が最も高い内的調 整と最も絶対值の大きい負の相関を示し、次の同一化的 調整ではその絶対值が小さくなる。そして、取り入れ的 調整では無相関、さらに外的調整では有意傾向ながら正 の相関を示した。したがって、在日外国人留学生のアル バイト活動においても、内発的調整や統合的調整、同一 化的調整に基づいてアルバイト活動を行っている留学生 は疲労感が低いことが予測される。特にその傾向は最も 自己決定性の高い内発的調整において顕著であろう。一 方、取り入れ的調整と外的調整に基づいてアルバイト活 動を行っている留学生は疲労感が高くなると予測される。 特にその傾向は、自己決定性の最も低い外的調整におい て顕著であろう。以上の予測を検証するために、本研究 では在日外国人留学生のアルバイト活動における動機づ け調整が職務満足感および疲労感に及ぼす影響について 検討を行うことを本研究の 1 つ目の目的とする。

さて、実際の個人の中にはある活動に対して複数の動 機づけが存在し、それらの動機づけの組み合わせで行動 が生起していると考えられる。たとえば、岡田・中谷(2006) では、大学生用学習動機づけ尺度の 4 つの下位尺度得点 をクラスター分析することにより、高動機づけスタイル、 自律スタイル、取り入れ・外的スタイル、低動機づけス タイルという4つの動機づけスタイルを見出している。 そして、動機づけスタイルによって課題への興味のあり 方や課題遂行中の不安が異なることが示されている。し たがって、在日外国人留学生のアルバイト活動において も、動機づけスタイルの種類によって、職務満足感や疲 労感が異なる可能性が指摘される。本研究の 2 つ目の目 的は、アルバイト動機づけ尺度の 5 因子を基にクラスター 分析を行うことによって個人の動機づけスタイルを分類 すると同時に、どの動機づけスタイルに属する人々の職 務満足感が高く、あるいは、どの動機づけスタイルに属 する人々の疲労感が低いのかについて明らかにすること である。

\section{2. 方法}

\section{1 調査協力者および手続き}

日本語学校および専門学校に在籍する外国人留学生 332 名を対象に質問紙調査を実施した。記入もれや回答ミス のあるデータ、在留資格が「留学」ではない者のデータ、 および、アルバイト経験のない者のデータを除き、有効 回答者 202 名（男性 118 名、女性 82 名、無回答 2 名、年 齢 $M=22.54$ 歳 $(S D=3.17))$ を分析対象とした。手続きは、 各学校の担当教員に、質問冊子の日本語が回答する留学 生にとって平易で分かりやすい表現になっているかにつ いて確認してもらったうえで、講義時間中において、筆 者または授業担当教員によって集団調査を行った。本調 査の目的、調査への参加は自由であること、回答しにく
い項目や意味がわかりにくい項目に対しては飛ばしても いいこと、および、調査による不利益は生じないことに ついてロ頭で説明したうえで、質問紙への回答を依頼し、 その場で回収した。

\section{2 調査内容}

(1)アルバイト動機づけ尺度（閻・堀内，2017）を用いた。 6（非常にあてはまる）から 1（全くあてはまらない）の 6 件法より回答を求めた。なお、本研究の対象は外国人留 学生であり、出席率の低下や留年がビザの更新に影響す るため、勉強よりアルバイト活動を優先することが考え にくいことから、統合的調整の 3 項目、寸なわち、「アル バイトを通じて学校生活では得られない経験ができるの で、他のことより優先したほうがいいと思うから」、「ア ルバイトを通じて日常生活では得られない経験ができる ので、他のことより優先したほうがいいと思うから」、「ア ルバイトを通じて学校で教えてくれない日本の常識が得 られるので、他のことより優先したほうがいいと思うか ら」に関して、「他のこと」とは勉強以外の活動に限られ ることを補足教示した。(2)閻・堀内（2019）と同様に全 体的職務満足感尺度（田中，1997）を基にアルバイト活動 用に改変して用いた。5（とてもそう思う）から１（全く そう思わない) の 5 件法より回答を求めた。(3)心理的ス トレス反応尺度（小杉・田中・大塚・種市・高田・河西 ・ 佐藤・島津・島津・白井・鈴木・山手・米原, 2004）にお ける「疲労」因子を用いた。5(とてもそう思う) から 1 (全 くそう思わない) の 5 件法より回答を求めた。(4)「学年」、 「年齢」、「出身国」、「在留資格」、「アルバイトの職種」、「勤 務時間（時間／回）」、「勤務頻度（回数／週）」、「継続年数」 について尋ねた。なお、質問紙には自己効力感を測定す る尺度も含まれていたが、本研究では結果の報告は割愛 する。

\section{3. 結果}

\section{1 調査協力者の内訳}

分析対象となった調査協力者の国籍は、中国 (92 名)、 ベトナム（78 名）、ネパール（11 名）、インドネシア（6 名）、 ミャンマー (6 名)、台湾 (2 名)、スリランカ (2 名)、韓 国 (1 名)、コロンビア (1 名)、トルコ (1 名)、カンボジ ア（1名）、イギリス（1名）によって構成される。勤務 頻度は週に平均 3.89 $(S D=1.35)$ 回、毎回の平均勤務時 間は 5.21 $(S D=1.74)$ 時間、アルバイト活動の平均継続 年数は 7.74 ケ月 $(S D=5.61)$ であった。また、職務内容 については、接客（飲食店のホールスタッフやコンビニ エンス・ストアの店員など）が最も多く（69名）、次は、 調理補助や洗い場、スーパーの惣菜（60 名）、工場（59名）、 介護 $(7$ 名)、配達 (6 名)、専門性の高い仕事（通訳やティー チング・アシスタントなど）（4名）、ホテルの掃除（3 名）、 不明（10名）となっている。

\section{2 各変数の基本的検討}

(1)アルバイト動機づけ尺度について、SPSS 25.0 を用い 
て因子分析 (最尤法・プロマックス回転)を行った結果、閻・ 堀内（2017）と同様の 5 因子構造が確認され、各因子に 含まれる項目も閻・堀内（2017） と同一であった（ $\alpha=.67$ 〜 .86)。(2)全体的職務満足感尺度について、最尤法によ る因子分析を行った結果、田中（1997）および閻・堀内 （2019）と同様に 1 因子構造が得られた $(\alpha=.74)$ 。(3)心理 的ストレス反応尺度における「疲労」因子について、最 尤法による因子分析を行ったところ、小杉他（2004）と 同様に 1 因子構造が得られた $(\alpha=.66)$ 。

\section{3 アルバイト動機づけの自己決定性が職務満足感およ び疲労感に及ぼす影響}

まず、下位尺度毎に項目の加算平均を下位尺度得点と して算出した（表 1)。各変数間の相関を求めたところ、 「職務満足感」に関しては、内発的調整 $(r=.46, p<.01)$ 、 統合的調整 $(r=.22, p<.01)$ 、同一化的調整 $(r=.28, p<$ .01）との間に正の相関が見られた。また、「疲労感」に関 しては、内発的調整 $(r=-.17, p<.05)$ と負の相関、外的 調整 $(r=.29, p<.01)$ と正の相関が示された。

次に、 5 つの動機づけ調整を独立変数、職務満足感およ び疲労感を従属変数とし、A mos 25.0 を用いて多変量回帰 分析を行った（図 1)。その結果、「職務満足感」に関して
は、内発的調整 $(\beta=.41, p<.01)$ および同一化的調整（ $\beta$ $=.19, p<.01)$ から有意な正のパス、取り入れ的調整（ $\beta=$ $-.16, p<.05)$ から有意な負のパスが示された。また、「疲 労感」に関しては、内発的調整 $(\beta=-.23, p<.01)$ から有 意な負のパス、外的調整 $(\beta=.28, p<.01)$ および同一化 的調整 $(\beta=.14, p<.01)$ から有意な正のパスが認められ た $\left(\chi^{2}(1)=.57(p=.45), \mathrm{GFI}=1.00, \mathrm{AGFI}=.98, \mathrm{RMSEA}=\right.$ $.00, \mathrm{CFI}=1.00)$ 。

\section{4 アルバイト動機づけスタイル、職務満足感および疲 労感の関連}

\subsection{1 アルバイト動機づけスタイルに関する検討}

5 つの下位尺度の因子得点を標準化したうえで、階層 的クラスター分析（ward 法、平方ユークリッド距離）を 行ったところ、解釈可能な 4 つのクラスターが見出され た。第 1 クラスター $(n=30: 14.85 \%)$ は、全体的にすべ ての下位尺度の得点が低いことに特徴づけられることか ら「低動機づけスタイル」と解釈した。第 2 クラスター $(n$ $=91: 45.05 \%)$ は、内発的調整が比較的高く、外的調整が 比較的低いことに特徵づけられることから「内発的微高・ 外的微低スタイル」と解釈した。第 3 クラスター $(n=36$ : $17.82 \%$ ）は、全体的にすべての下位尺度の得点が高いこ

表 1 : 各下位尺度の記述統計量および相関係数 $(N=202)$

\begin{tabular}{lcccccccc}
\hline \multicolumn{1}{c}{ 尺度 } & $M(S D)$ & 1 & 2 & 3 & 4 & 5 & 6 & 7 \\
\hline 1. 内発的調整 & $3.31(1.35)$ & - & & & & & & \\
2. 統合的調整 & $3.85(1.20)$ & $.37 * *$ & - & & & & \\
3. 同一化的調整 & $4.76(0.99)$ & $.23 * *$ & $.23 * *$ & - & & & \\
4. 取り入れ的調整 & $3.05(1.44)$ & $.16 *$ & $.37 * *$ & .14 & - & & \\
5. 外的調整 & $3.89(1.43)$ & .04 & $.24 * *$ & .08 & $.22 * *$ & - & \\
6. 職務満足感 & $3.29(0.86)$ & $.46 * *$ & $.22 * *$ & $.28 * *$ & -.05 & -.03 & - & - \\
7. 疲労感 & $3.10(0.82)$ & $-.17 *$ & .05 & .12 & .09 & $.29 * *$ & -.11 & - \\
\hline
\end{tabular}

注: ${ }^{*} p<.05, * * p<.01$ 。

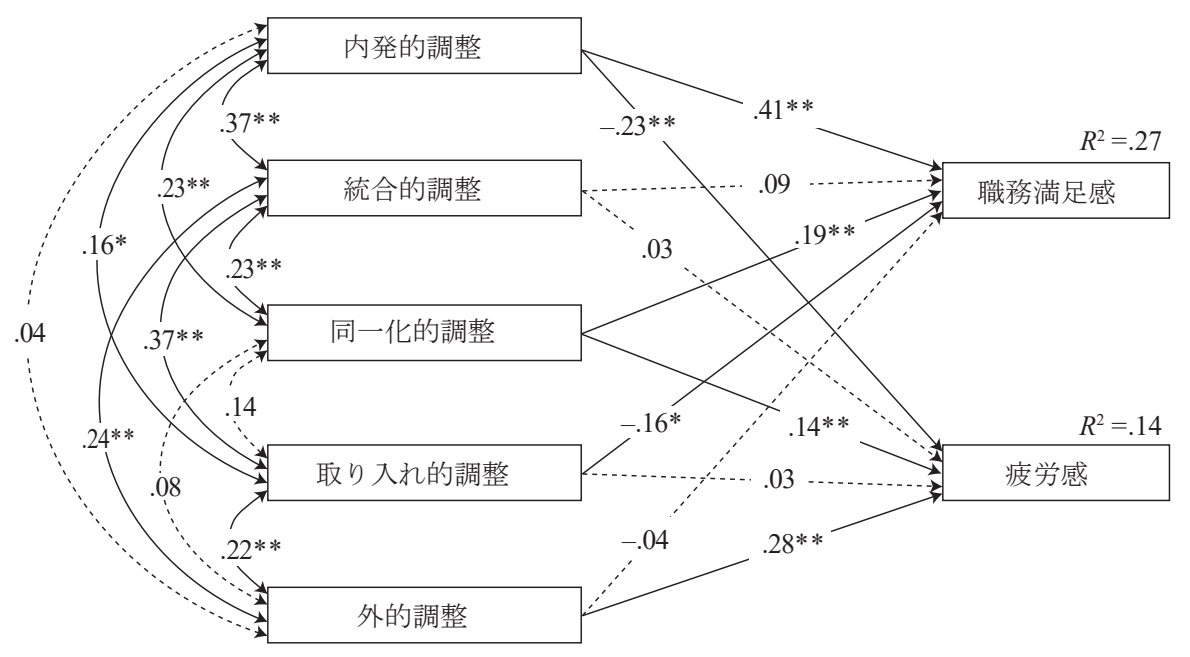

図 1 : 動機づけの自己決定性が職務満足感および疲労に及ぼす影響

注 : 実線は有意なパス、点線は有意ではないパスを示す。誤差変数の図示は省略した。* $p<.05, * * p<.01$ 。 
表 2 : アルバイト動機づけスタイルごとの動機づけ下位尺度得点 $(z)$ および職務満足感と疲労感の平均值（標準偏差）

\begin{tabular}{lccccccc}
\hline & 外的調整 & 取り入れ的調整 & 同一化的調整 & 統合的調整 & 内発的調整 & 職務満足感 & 疲労感 \\
\hline 1. 低動機づけスタイル & -0.53 & -0.93 & -1.02 & -1.20 & -1.19 & $2.90(0.90)$ & $2.95(0.91)$ \\
2. 内発的微高・外的微低スタイル & -0.38 & 0.02 & 0.02 & -0.19 & 0.35 & $3.41(0.76)$ & $2.98(0.72)$ \\
3. 高動機づけスタイル & 0.64 & 0.23 & 0.71 & 1.03 & 1.14 & $3.88(0.61)$ & $3.03(0.81)$ \\
4. 内発的低・外的高スタイル & 0.62 & 0.39 & 0.08 & 0.37 & -0.82 & $2.82(0.81)$ & $3.49(0.81)$ \\
\hline
\end{tabular}

とに特徴づけられることから「高動機づけスタイル」と 解釈した。第 4 クラスター $(n=45: 22.28 \%)$ は、内発的 調整が低く、外的調整が高いことに特徵づけられること から「内発的低・外的高スタイル」と解釈した（表 2)。

\section{4 .2 各動機づけスタイルにおける職務満足感と疲労感}

まず、4つの動機づけスタイルを独立変数、職務満足感 を従属変数とする 1 要因 4 水準参加者間の分散分析を行っ た（表 2)。その結果、職務満足感については、要因の効 果が見られた $\left(F(3,198)=15.55, p<.01, \eta^{2}=0.19\right) 。 5 \%$ 水準の Bonferroni 法による多重比較を行った結果 $(M S e=$

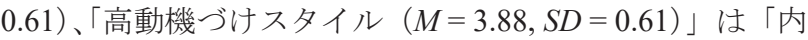
発的微高・外的微低スタイル $(M=3.41, S D=0.76) 」$ より も職務満足感が高く、「内発的微高・外的微低スタイル」 は「内発的低・外的高スタイル $(M=2.82, S D=0.81) 」$ と

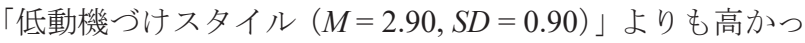
た。一方、「内発的低・外的高スタイル」と「低動機づけ スタイル」との間には有意な差が認められなかった。

次に、4つの動機づけスタイルを独立変数、疲労感を 従属変数とする 1 要因 4 水準参加者間の分散分析を行っ た (表 2)。その結果、疲労感については、要因の効果が 見られた $\left(F(3,198)=4.76, p<.01, \eta^{2}=0.07\right)$ 。 $5 \%$ 水準の Bonferroni 法による多重比較を行ったところ $(M S e=0.64)$ 、 「内発的低・外的高スタイル $(M=3.49, S D=0.81) 」$ は、高 動機づけスタイル $(M=3.03, S D=0.81) 」$ 、「内発的微高・ 外的微低スタイル $(M=2.98, S D=0.72) 」$ 、「低動機づけス タイル $(M=2.95, S D=0.91) 」 よ り も$ 疲労感が高かったが、 3 スタイルの間には有意な差が見られなかった。

\section{4. 考察}

本研究の 1 つ目の目的は、在日外国人留学生のアルバ イト活動における動機づけ調整が職務満足感および疲労 感に及ぼす影響について検討することであつた。5つの動 機づけ調整を独立変数、職務満足感と疲労感をそれぞれ 従属変数とした多変量回帰分析を行った。職務満足感に 対しては、内発的調整、同一化的調整が正の関連を示した。 すなわち、アルバイト活動自体に楽しさを感じ、アルバ イトを自分自身の成長の糧と認識して、アルバイト活動 を持続している留学生であるほじ、職務に対してより高 い満足感を感じると考えられる。また、取り入れ的調整 から負の相関が見られた。すなわち、義務や責任によっ てアルバイトを続けている場合は、職務満足感が低くな る可能性があると考えられる。これらの結果は概ね閻・
堀内 $(2017 ; 2019)$ を踏襲するものであり、本研究が先行 研究と同様に適切に行われたことを示す傍証とみなすこ とができよう。

さて、本研究の主眼である疲労感に関する結果だが、 外的調整から正の相関が見られた。すなわち、在日外国 人留学生が生活費を稼ぐという外的な要因に強制される ことによって、圧迫感を感じ、疲労に至ると考えられる。 また、内発的調整から疲労感への負の関連が見られたこ とから、アルバイト活動自体が行動の目的であり、その 仕事内容に対して関心や興味を持つことによって、仕事 に対する疲労感が抑制されると考えられる。ところで、 同一化的調整は、職務満足感と正の関連を示したが、そ の一方で、疲労感とも正の相関を示すというアンビバレ ンツな結果が得られた。同一化的調整は、アルバイト活 動がもつ価值を認識し、アルバイト活動を通して日本語 能力を高めようとする動機づけである。同一化的調整は 比較的自律的な外発動機づけであり、職務満足感との正 の関連は理論的な予測に合致するものである。閻・堀内 （2017）においても同様の正の関連が得られている。しか しながら、同一化的調整の本質は外発動機づけである。 島津・小杉（1998）では、職務に必要な知識や技術が不 足するという「能力欠如」が疲労をもたらすことが見出 されている。アルバイト活動を通じて日本語能力を高め ようと動機づけられているが故に、アルバイト活動で日 本語能力や対人関係スキルの不足を痛感せざるを得ない 場面に遭遇した場合には、高い疲労感を生じてしまう可 能性が指摘される。

本研究の $2 つ$ 目の目的は、個人の動機づけスタイルを 特定し、各動機づけスタイルがもたらす職務満足感およ び疲労感の相違を検討することであった。5つの動機づけ 調整をもとにクラスター分析を行った結果、4つの動機づ けスタイル「低動機づけスタイル」「内発的微高・外的微 低スタイル」「高動機づけスタイル」「内発的低・外的高 スタイル」が見出された。職務満足感が最も高かったの は「高動機づけスタイル」であり、次に「内発的微高・ 外的微低スタイル」が続き、以降の 2 つの動機づけスタ イル間には有意な差はなかった。先行研究 (Gillet, Morin, \& Reeve, 2017; Ratelle, Guay, Vallerand, Larose, \& Senécal, 2007）では、「内発的調整と同一化的調整が相対的に高く、 取り入れ的調整と外的調整が相対的に低い動機づけス夕 イル」が適応的な状態につながることが指摘されており、 それは本研究の「内発的微高・外的微低スタイル」に相 当する。しかしながら、本研究の研究対象は職業領域で 
あり、アルバイト活動では給料を得ることが絶対的な条 件であるため、在日外国人留学生がアルバイト活動自体 の楽しさや個人の成長に対する重要性、労働者としての 責任感を認識すると同時に、金銭的側面も重視している と考えられる。

疲労感に関しては、「内発的低・外的高スタイル」のみ が高く、その他の 3 つの動機づけスタイルは同程度に得 点が低いことが確認された。「内発的低・外的高スタイル」 の在日外国人留学生は、外的要因に統制されていること を強く認識し、日々のアルバイト活動の中で不安や緊張 などのネガティブな感情を感じ、疲労感につながる可能 性が高いと考えられる。本研究の結果は、内発的調整が 低く、外的調整が高いスタイルが不適応指標である疲労 感を予測することが示され、自己決定理論の理論背景を 反映したものであると考えられる。

本研究が有する問題点について述べる。第 1 は、本研 究では、アルバイト活動における不適応を検討するため に、職務ストレス反応の中核である「疲労感」を取り上 げた。しかしながら、疲労感は職務ストレス反忘を構成 する変数の 1 つに過ぎず、今後の研究では、より広範な ストレス指標を設定し、アルバイト動機づけとの関連を 検討することが必要であろう。第 2 は、本研究は一時点 でデータを収集した横断調査であり、因果関係を厳密に は言及できない。今後の研究では、複数の時点でデータ を収集する縦断調査を行うことが望まれる。第 3 は、本 研究では複数のアルバイトに従事していると回答した留 学生が 5 名いたが、彼らに対して、どれか一つを何らか の基準で選んで回答するのか、それともアルバイト全般 について回答するのかを明確に教示しなかったため、当 該留学生の回答が漠然で曖昧になってしまった可能性が ある。

近年、景気回復に伴い、労働需要の高まりによって雇 用情勢が着実に改善する一方で、労働供給が完全には追 いついておらず、企業の人手不足感が高まりつつある（内 閣府, 2018)。人員が不足している企業のうち、外国人材 の受入れニーズがあると回答した企業は全体の $57.8 \%$ で あり、深刻な人手不足の中で外国人材に対する期待と関 心が高くなっている（日本・東京商工会議所, 2019）。ア ルバイト活動にはキャリア形成（関口，2010）や進路選択 自己効力（川瀬，2015）を高める効果があることから、外 国人留学生のアルバイト活動における職務満足感を向上 させ、疲労感を低減させることは、外国人留学生を国内 の企業に誘致するうえで重要であると考えられる。閻・ 堀内（2019）では自律性・有能感・関係性への欲求とい う3つの心理的欲求の充足が自律的な動機づけを高める ことを明らかにしている。本研究で自律的な動機づけが 疲労感を低減することが示されたことから、疲労感に対 して 3 つの心理的欲求から自律的な動機づけを介した間 接効果が期待される。すなわち、3つの心理的欲求に関す る適切なサポートを提供することが、疲労感を低減する 有効な手段であると考えられる。なお、統制的な動機づ けを介した疲労感の低減方法の開発に関しては今後の重
要な研究課題であろう。

\section{引用文献}

Deci, E. L. \& Ryan, R. M. (1985). Intrinsic motivation and selfdetermination in human behavior. New York: Plenum Press.

独立行政法人日本学生支援機構 (2019a). 平成 29 年度 私費外国人留学生生活実態調查概要. Retrieved from https://www.jasso.go.jp/about/statistics/ryuj_chosa/h29. html.（2019年 10 月 4 日)

独立行政法人日本学生支援機構 $(2019 b)$. 平成 30 年度 外国人留学生在籍状況調查結果. Retrieved from https:// www.jasso.go.jp/about/statistics/intl_student_e/2018/index. html. (2019 年 10 月 4 日)

Gillet, N., Morin, A. J. S., \& Reeve, J. (2017). Stability, change, and implications of students' motivation profiles: A latent transition analysis. Contemporary Educational Psychology, 51, 222-239.

川瀬隆千 (2015). 宮崎公立大学学生の進路選択自己効力 の要因としての遂行体験. 宮崎公立大学人文学部紀要, $23,1-12$.

小杉正太郎・田中健吾 - 大塚泰正 - 種市康太郎 - 高田未里 河西真知子 - 佐藤澄子 - 島津明人 - 島津美由紀 - 白井 志之夫・鈴木綾子・山手裕子・米原奈緒 (2004). 職場 ストレススケール改訂版作成の試み (I) 一ストレッサー 尺度・ストレス反応尺度・コーピング尺度の改訂一. 産業ストレス研究, 11, 175-185.

厚生労働省 (2019). 「外国人雇用状況」の届出状況（概 要版）（平成 30 年 10 月末現在). Retrieved from https:// www.mhlw.go.jp/content/11655000/000472891.pdf. (2019 年 10 月 4 日)

文部科学省・外務省・法務省・厚生労働省・経済産業 省・国土交通省 (2008).「留学生 30 万人計画」骨 子. Retrieved from http://www.mext.go.jp/a_menu/koutou/ ryugaku/1420758.htm. (2019 年 10 月 4 日)

永作稔・新井邦二郎 (2005). 自律的高校進学動機と学校 適応・不適応に関する短期縦断的検討. 教育心理学研究, $53,516-528$.

内閣府 (2018). 人手不足感の高まりについて. Retrieved from https://www5.cao.go.jp/keizai3/monthly_topics/2018/0302/topics_052.pdf.（2019年 10 月 4 日）

日本・東京商工会議所 (2019). 「人手不足等への対応に 関する調査」結果概要. Retrieved from https://www.jcci. or.jp/hitodebusoku.pdf. (2019 年 10 月 4 日)

岡田涼 (2005). 友人関係への動機づけ尺度の作成および 妥当性・信頼性の検討一自己決定理論の枠組みから一. パーソナリティ研究, 14, 101-112.

岡田涼・中谷素之 (2006). 動機づけスタイルが課題への 興味に及ぼす影響一自己決定理論の枠組みから一. 教 育心理学研究, 54, 1-11.

Ratelle, C. F., Guay, F., Vallerand, R. J., Larose, S., \& Senécal, C. (2007). Autonomous, controlled, and amotivated types of academic motivation: A person-oriented analysis. Journal of 
Educational Psychology, 99, 734-746.

Richer, S. F., Blanchard, C., \& Vallerand, R. J. (2002). A motivational model of work turnover. Journal of Applied Social Psychology, 32, 2089-2113.

Roth, G., Assor, A., Kanat-Maymon, Y., \& Kaplan, H. (2007). Autonomous motivation for teaching: How self-determined teaching may lead to self-determined learning. Journal of Educational Psychology, 99, 761-774.

Ryan, R. M. \& Deci, E. L. (2000). Self-determination theory and the facilitation of intrinsic motivation, social development, and well-being. American Psychologist, 55, 68-78.

関口倫紀 (2010). 大学生のアルバイト経験とキャリア形 成. 日本労働研究雑誌, 52, 67-85.

島津明人・小杉正太郎 (1998). 職場不適応発生過程の検討. 心理学研究, 69, 198-205.

田中美由紀 (1997). 職務満足感に関する諸要因の検討. 早稲田心理学年報, 30, 29-36.

閻琳・堀内孝 (2017)。在日外国人留学生を対象としたア ルバイト動機づけ尺度の作成. パーソナリティ研究, 26, 99-108.

閻琳・堀内孝 (2019). 在日外国人留学生のアルバイト職 務満足感一自己決定理論に基づく検討一. 心理学研究, 90, 178-186.

(受稿 : 2020 年 6 月 2 日 受理 : 2020 年 8 月 25 日) 